\title{
Seasonal changes in fish assemblage structure at a shallow seamount in the Gulf of California
}

\author{
Salvador J Jorgensen ${ }^{\text {Corresp., }}{ }^{1,2}$ ， A. Peter Klimley ${ }^{2}$, Arturo Muhlia-Melo ${ }^{3}$, Steven G Morgan ${ }^{4}$ \\ ${ }^{1}$ Conservation Research Department, Monterey Bay Aquarium, Monterey, California, United States \\ 2 Department of Wildlife, Fish, \& Conservation Biology, University of California, Davis, Davis, California, United States \\ 3 Department of Fisheries Ecology, Centro de Investigaciones Biológicas del Noroeste S. C., La Paz, Baja California Sur, Mexico \\ 4 Bodega Marine Lab, University of California, Davis, Bodega Bay, California, United States \\ Corresponding Author: Salvador J Jorgensen \\ Email address: sjorgensen@mbayaq.org
}

Seamounts have generally been identified as locations that can promote elevated productivity, biomass and predator biodiversity. These properties attract seamountassociated fisheries where elevated harvests can be obtained relative to surrounding areas. There exists large variation in the geological and oceanographic environment among the thousands of locations that fall within the broad definition of seamount. Global seamount surveys have revealed that not all seamounts are hotspots of biodiversity, and there remains a strong need to understand the mechanisms that underlie variation in species richness observed. We examined the process of fish species assembly at El Bajo Espiritu Santo (EBES) seamount in the Gulf of California over a five-year study period. To effectively quantify the relative abundance of fast-moving and schooling fishes in a 'blue water' habitat, we developed a simplified underwater visual census (UVC) methodology and analysis framework suitable for this setting and applicable to future studies in similar environments. We found correlations between seasonally changing community structure and variability in oceanographic conditions. Individual species responses to thermal habitat at EBES revealed three distinct assemblages, a 'summer assemblage' tracking warmer overall temperature, a 'winter assemblage' correlated with cooler temperature, and a 'year-round assemblage' with no significant response to temperature. Species richness was greatest in spring, when cool and warm water masses stratified the water column and a greater number of species from all three assemblages co-occurred. We discuss our findings in the context of potential mechanisms that could account for predator biodiversity at shallow seamounts. 


\section{Seasonal changes in fish assemblage structure at a shallow seamount}

\section{2 in the Gulf of California}

3

4 Salvador J. Jorgensen ${ }^{\mathrm{a}, \mathrm{b}}$, A. Peter Klimley ${ }^{\mathrm{b}}$, Arturo Muhlia-Melo ${ }^{\mathrm{c}}$, Steven G. Morgan ${ }^{\mathrm{d}}$

5

6

7

8

9

10

11 CA 93940, sjorgensen@mbayaq.org

12

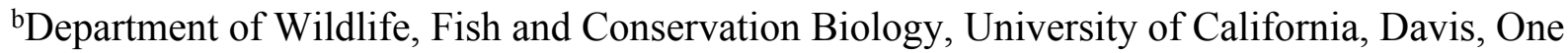

14 Shields Avenue, CA 95616, USA, sjorgensen@mbayaq.org

15

16

'Department of Fishereies Ecology, Centro de Investigaciones Biologicas del Baja California

17 Sur, Apartado Postal 128, La Paz, Mexico, amuhlia04@cibnor.mx

18

19

20

dBodega Marine Laboratory, P.O. Box 247 Bodega Bay, CA 94923, USA,

sgmorgan@ucdavis.edu

21

22 


\section{Abstract.}

25 Seamounts have generally been identified as locations that can promote elevated productivity,

26 biomass and predator biodiversity. These properties attract seamount-associated fisheries where

27 elevated harvests can be obtained relative to surrounding areas. There exists large variation in the

28 geological and oceanographic environment among the thousands of locations that fall within the

29 broad definition of seamount. Global seamount surveys have revealed that not all seamounts are

30 hotspots of biodiversity, and there remains a strong need to understand the mechanisms that

31 underlie variation in species richness observed. We examined the process of fish species

32 assembly at El Bajo Espiritu Santo (EBES) seamount in the Gulf of California over a five-year

33 study period. To effectively quantify the relative abundance of fast-moving and schooling fishes

34 in a 'blue water' habitat, we developed a simplified underwater visual census (UVC)

35 methodology and analysis framework suitable for this setting and applicable to future studies in

36 similar environments. We found correlations between seasonally changing community structure

37 and variability in oceanographic conditions. Individual species responses to thermal habitat at

38 EBES revealed three distinct assemblages, a 'fall assemblage' tracking warmer overall

39 temperature, a 'spring assemblage' correlated with cooler temperature, and a 'year-round

40 assemblage' with no significant response to temperature. Species richness was greatest in

41 summer, when cool and warm water masses stratified the water column and a greater number of

42 species from all three assemblages co-occurred. We discuss our findings in the context of

43 potential mechanisms that could account for predator biodiversity at shallow seamounts. 


\section{Introduction.}

Seamounts have long been identified as important ocean habitats with elevated predator diversity (Hubbs, 1959; Morato et al., 2010a). Multi-species aggregations of fishes are commonly reported at shallow seamounts (Klimley \& Butler, 1988; Rogers, 1994; Morato \& Clark, 2007). These aggregations are targeted by numerous fisheries and data suggest that catch rates for many fish species are higher near some seamounts relative to surrounding habitats (Rogers, 1994; Genin, 2004; Morato et al., 2008). Shallow seamounts consist of relatively shallow benthic habitat, within the euphotic zone, surrounded by adjacent deep-ocean (Lueck \& Mudge, 1997; Trasvina-Castro et al., 2003; Clark et al., 2010; Staudigel et al., 2010). Thus fishes aggregating at these sites are demersal and reef-associated, as well as pelagic species common in epipelagic environments (Holland \& Grubbs, 2007; Litvinov, 2007; Morato \& Clark, 2007;

Morato et al., 2008). However, seamounts are highly variable in their geologic and oceanographic characteristics, and not all seamounts have fish aggregating properties (Kvile et al., 2014). Among the potential mechanisms and drivers, examining the oceanographic conditions promoting seamount productivity, predator aggregation, and species richness remains an important research gap (Clark et al., 2012; McClain \& Lundsten, 2015; Morato et al., 2015). Tracking seamount community assembly over time in relation to natural oceanographic variability can provide unique insights into seamount ecology.

The mechanisms for why fishes sometimes occur in higher densities at shallow seamounts fall into two general categories. First, some seamounts may provide elevated foraging opportunities. Trophic subsidies likely result as seamounts generate conditions such as increased vertical nutrient fluxes and plankton retention that increase productivity and fuel higher trophic levels (Lueck \& Mudge, 1997; Genin, 2004). Second, seamounts may provide spatial reference 
69 points or refugia for migratory species (Klimley, 1993; Freon \& Dagorn, 2000). However, the

70 processes that determine the composition of fish species and elevated predator richness have

71 received comparatively little attention, and remain uncertain (McClain, 2007; Morato et al., 72 2010a).

73

One hypothesis for increased fish species richness at seamounts is the enhanced

75

\section{1} availability of limiting trophic resources (Worm, Lotze \& Myers, 2003; McClain, 2007; Morato et al., 2010a). This idea is essentially an extension of the 'species-energy' hypothesis (Wright, 1983), which predicts that the diversity of one trophic level is determined by the amount of energy available from the level below. If elevated forage availability at seamounts supports a greater number of individuals and, in turn, species richness, then food should be the primary resource of interest for fishes that visit seamounts, and more visitors (species) should occur when food supply is elevated.

83

4
which provide a variety of resources and environmental conditions suitable for a range of fish species and life history functions. The 'habitat heterogeneity' hypothesis is a long-standing tenet of terrestrial ecology (e.g. Simpson, 1949; MacArthur \& Wilson, 1967; Tews et al. 2004) whereby structurally complex habitats may provide more ways of exploiting environmental resources and thereby increase species diversity. Under this hypothesis more species are predicted to co-occur when habitat is more complex, or when the breadth of resources exploited increases. To explore processes of seamount community assembly and variation in fish species richness we tracked the relative abundance of conspicuous shallow seamount-associated fish species at El Bajo Espiritu Santo (EBES) seamount over a five-year period. To overcome the 
95 difficulty in quantifying relative abundance for fast-moving and schooling fishes in a 'blue

96 water' habitat, we developed a simplified underwater visual census (UVC) methodology and

97 analysis framework suitable for this setting and applicable to future studies in similar

98 environments. We compared the results of UVCs and experimental fishing surveys over time

99 with oceanographic parameters to determine how changes in seamount community structure

100 correlated with natural environmental variability. We discuss the results in the context of two

101 hypotheses, 'species-energy' and 'habitat heterogeneity' as they relate to seamounts as predator

102 diversity hotspots.

103

104 Methods.

105 Study area

106 El Bajo Espiritu Santo Seamount (EBES) is located in the lower Gulf of California

$107\left(24^{\circ} 42^{\prime} \mathrm{N}, 110^{\circ} 18^{\prime} \mathrm{W}\right) 56 \mathrm{~km}$ north of La Paz (Fig. 1a). The summit of the seamount reaches a

108 minimum depth of $18 \mathrm{~m}$ and drops off to between approximately 500 and $1000 \mathrm{~m}$ on all sides (for

109 detailed bathymetric view see Fig. 1 in Klimley, 1993). The upper part of the seamount, within

$11030 \mathrm{~m}$ of the surface, forms a broad ridge that is approximately $500 \mathrm{~m}$ long and $100 \mathrm{~m}$ wide.

111 Numerous demersal, reef-associated and pelagic fish species inhabited the water column between

112 this ridge and the water surface, and this seamount-associated community was the focus our

113 study.

114

115 Underwater visual censuses

116 We conducted underwater visual censuses (UVCs) at EBES from 1999 to 2004 by

117 measuring encounter rates for individuals of 27 conspicuous predator and prey fish species

118 (Table 1) along transects using SCUBA. Divers recorded the identity and number of individuals 
119 of each target species encountered on a waterproof slate. Data were consistently collected by the

120 same few divers throughout the study. Transects were initiated at random starting points near one

121 end of the seamount ridge and proceeded on a compass bearing along its length in either a

122 northwesterly or southeasterly direction. If currents were too strong to swim against, the census

123 was initiated at a random starting point near the up-current end of the ridge, allowing divers to

124 drift with the current. Censuses proceeded for 40 minutes while divers swam toward a constant

125 compass bearing at a relatively constant speed of approximately $0.2 \mathrm{~ms}^{-1}$. In order to sample

126 across all depths between 0 and $30 \mathrm{~m}$ while maintaining safe SCUBA protocols, divers began

127 sampling immediately upon leaving the surface while gradually descending. Once the maximum

128 depth was reached ( 25 to $30 \mathrm{~m}$ ), divers began a very gradual ascent with a goal of reaching the

129 surface at the 40 minute mark. Fish were only counted if they appeared within $5 \mathrm{~m}$ of the

130 observer in any direction forward of a plane perpendicular to the swimming direction. Visibility

131 was estimated by divers from the difference between the depth of the seamount substrate and the

132 depth at which this substrate first became visible as the diver descended toward it. Visibility was

133 measured only when a light patch of sand near the seamount summit $(20 \mathrm{~m})$ was not visible from

134 the boat at the surface. During censuses, visibility ranged from $7 \mathrm{~m}$ to $>20 \mathrm{~m}$.

135 Among species, considerable variability occurred in the number of individuals

136 encountered per observation. For example, green jacks (C. caballus) often occurred in large

137 schools $(\mathrm{n}>128)$ when present at the seamount, while yellowtail (S. lalandi) counts seldom

138 exceeded 12 individuals per transect. Additionally, several species were generally either absent

139 from the seamount or present in large numbers. To minimize bias and sampling error, we

140 organized our counts into classes or ' 'bins' with central values expressed on a $\log ^{2} \operatorname{scale}$, i.e.

141 centers 0 and $2^{i}$ where $i=0-7$. For example $2^{0}$ denotes a count of one individual, $2^{1}$ represents a 
142 class of between 1.4 and 2.8 individuals $\left(2^{0.5}-2^{1.5}\right)$ with a central value of 2 , and $2^{2}$ refers to a

143 class of 2.9 - 5.6 individuals $\left(2^{1.5}-2^{2.5}\right)$ with a central value of four, and so forth (Table 2). Thus,

144 bin width expanded exponentially with the number of individuals counted assuring that even

145 large numbers of rapidly moving fish could be accurately estimated to be within one of the range

146 categories. When the number of individuals was too large or difficult to count accurately during

147 censuses, the number was estimated to the nearest central value and corresponding ordinal score.

148 This procedure provided an objective criterion for quickly sorting raw counts into a number of

149 ordinal categories. Additionally this procedure resulted in a log-transformation of the data,

150 thereby increasing the 'spread' and resolution for species with lower counts (see Tables 2 and 3)

152 Fishing surveys

153 After each census, we conducted standardized fishing surveys to detect species that were

154 less frequently encountered while using SCUBA. We recorded captures (presence or absence) of

155 Thunnus albacares, Corphaena hippurus, and Acanthicybium solanrdi during 60-min fishing

156 periods. Our tackle consisted of monofilament line that was attached directly to a hook, and

157 baited with a single herring, Harengula thrissina. Three of these 20-m long rigs were deployed

158 simultaneously while the boat drifted over the seamount. Ethical review was not required for

159 sampling of marine fishes in fishing surveys.

160

161 Environmental records

162 At EBES, we recorded daily water temperature at a depth of $30 \mathrm{~m}$ using an in situ

163 temperature logger (Onset Corporation, Tidbit Stowaway, and Water Temp Pro). Sea surface

164 temperature (SST14NA) was downloaded from the National Environmental Satellite, Data, and 
165 Information Service (NESDIS) online database (www.class.noaa.gov). This SST14NA product

166 was generated every 48 hours and referenced to in situ measurements at $1 \mathrm{~m}$ depth. Temperature

167 profile were obtained opportunistically from casts taken at points along SW-NE transects that

168 bisected EBES (Trasvina-Castro et al., 2003) on November 24, 1997, September 10, 1998, and

169 June 22, 1999. Data collected $\leq 5 \mathrm{~km}$ from the seamount $(\mathrm{n}=4-7)$ were partitioned into depth

170 bins and averaged for each date. A fourth temperature/depth profile was acquired from a data

171 archiving tag (Wildlife Computers Inc., PAT), which was attached to a shark (Sphyrna lewini) at

172 EBES. Minimum and maximum temperatures were recorded from seven depths $(4,16,100,156$,

173260,316 , and $368 \mathrm{~m}$ ) as the shark swam through the water column shortly after tagging on

174 February 2, 2004. These data were later transmitted from the tag via satellite after the tag

175 released from the shark (Jorgensen, Klimley \& Muhlia-Melo, 2009).

176

177 Analysis

178 Censuses were conducted at irregular intervals over the duration of the study period. Each

179 independent observation was recorded as the mean value of replicate censuses $(n=1-4)$ that

180 were completed within a calendar month. The mean number of encounters per transect for each

181 species was then given an ordinal score following the $\log _{2}$ classification scheme (see table 2). To

182 examine the influence of seasonal oceanographic processes on the relative abundance of pelagic

183 species at EBES, we used multiple logistic regression analysis (SAS Institute Inc., JMP). Of 27

184 species observed at the seamount, we considered only those present in $>10 \%$ of census

185 observations ( $\mathrm{n}=17$ species $)$ for analysis. Ordinal score was regressed over monthly mean SST

186 and monthly mean water temperature at $30 \mathrm{~m}$ depth (T30). We used the same technique for

187 analyzing our fishing survey data, except the dependent variable was binary (presence and 
188 absence) rather than ordinal. To verify the assumption of temporal independence among

189 observations, we performed time series analysis on the regression residuals. There was no

190 significant autocorrelation at any lag time for any species $(\alpha= \pm 2 \mathrm{SE})$. T30 measurements were

191 not collected during three months, October 2003, May 2004, and June 2004, and a value was

192 estimated for these months by averaging temperatures of the respective months collected during

193 all other years $(n=5-6)$.

194

To further understand temporal patterns in the co-occurrence of seamount species we

196 plotted species abundance curves over time. This qualitative gradient analysis facilitated

197 visualizing the seasonal separation and overlap of species at the seamount. We summarized

198 census data from all five years into a single seasonal cycle (12 months) by taking the mean of all

199 the census scores for each species by month, then normalizing by the highest value, so that

200 relative abundance could be compared among species. We then fit a curve though the monthly

201 values for each species using locally weighted smoothing via least squares quadratic polynomial

202 fitting (Loess fit; Matlab ${ }^{\mathrm{TM}}$, Mathworks).

203

204 To compare the number of species present at the seamount with sea temperature, the

205 presence or absence of the 17 species was summarized by month. A species was scored as

206 present if it was observed during that month in any year during the study. An index of species

207 richness for each month was determined as the sum of the number of target species that were

208 present. The temperature gradient near the surface (SST - T30) during each month was

209 calculated as the mean difference between SST and T30 over all years. We used standard linear 
210 regression analysis to determine whether there was a significant correlation between the number

211 of species observed and SST, T30, or near-surface temperature gradient.

212

213 Results.

214 Oceanographic environment

215 The seamount environment was characterized by substantial variation in temperature both

216 temporally and in terms of vertical thermal gradient. However, the annual cyclic pattern was

217 relatively predictable. Between 1999 and 2005 the mean 2-day Sea Surface Temperature at

218 EBES was $24.4^{\circ} \mathrm{C}$ and ranged from 18.3 to $32.5^{\circ} \mathrm{C}$ (Fig. 1B). Sea surface temperature generally

219 peaked near $32{ }^{\circ} \mathrm{C}$ in August and September then decreased rapidly from October through

220 January to a low near $19{ }^{\circ} \mathrm{C}$ in February and March. Throughout summer, STT increased steadily

221 but gradually. Mean daily T30 was $21.8^{\circ} \mathrm{C}$ and ranged from 16.1 to $29.8^{\circ} \mathrm{C}$ with maxima during

222 September and October and minima from January to June. Colder deep water persisted during

223 the spring and early summer as surface temperatures warmed, resulting in a strong and shallow

224 thermocline that lasted through July. T30 then typically rose sharply to its yearly high peak. By

225 November both SST and T30 typically fell rapidly as mixing deepened.

226

227

Periodic temperature profile measurements at EBES revealed the extent of seasonal

228 changes throughout the water column. Most annual variability occurred above $200 \mathrm{~m}$ (Fig. 2).

229 Temperature was relatively constant $\left(\sim 13^{\circ} \mathrm{C}\right)$ at $200 \mathrm{~m}$ depth but there were considerable

230 differences in the depth of the mixed layer and the degree of stratification in the upper near-

231 surface layer. Although SSTs were similar in June and November $\left(\sim 27^{\circ} \mathrm{C}\right)$ the temperature cast

232 from June 1999 revealed strong stratification with a gradient of $>8^{\circ} \mathrm{C}$ in the top $30 \mathrm{~m}$. This 
233 observation is consistent with the average observed difference between mean SST and T30 in

234 June (mean $=8.4)$, as shown by the difference between the gray line and dark line each June in

235 Fig. 1c. The cast from November revealed a deep mixed layer extending to $\sim 70 \mathrm{~m}$. This deep

236 mixing generally persisted through December.

237

238 Censuses

239 A total of 53 individual census dives were conducted at irregular intervals over 62

240 months from May 1999 to Aug 2004. These were averaged by calendar month resulting in 26

241 independent observations over the study period (Table 3). The relative abundance of species

242 encountered during censuses at EBES at different times of the year revealed changes in the

243 community structure. For many species, a clear seasonal signal was evident when relative

244 abundance was plotted over time against SST and T30. For example, Seriola lalandi was

245 generally absent from the seamount during warm seasons, but generally peaked in abundance

246 from January to April, when temperatures were low $\left(\sim 20^{\circ} \mathrm{C}\right.$; Fig. 3A). In contrast, peaks in

247 Lutjanus novemfasciatus abundance coincided with positive peaks in SST and T30 between

248 August and November when temperatures were high $\left(\sim 27\right.$ and $32^{\circ} \mathrm{C}$ respectively; Fig. $\left.3 \mathrm{~b}\right)$.

Sea surface temperature and T30 were both significant predictors (multiple logistic

regression, $\mathrm{P}<0.05$ ) of seasonal relative abundance for eight species (Table $\mathrm{S} 1$ ). There was also 252 a significant nominal (presence or absence) response $(\mathrm{P}<0.05)$ to $\mathrm{STT}$ and $\mathrm{T} 30$ for C. hippurus, 253 based on fishing surveys (Table S1). To better understand the differing responses to

254 oceanographic cycles by community members, we used the coefficients of the two regressors

$255\left(\beta_{\mathrm{SST}}\right.$ and $\left.\beta_{\mathrm{T} 30}\right)$ as ordination axes and plotted each species in relation to these environmental 
256 gradients (Fig. 4; Table S1). For negative $\log$-likelihood, a negative $\beta$ values along either axis

257 denotes a positive effect, and a positive $\beta$ value indicates the opposite. Therefore, higher positive

258 values for a combination of $\beta_{\mathrm{SST}}$ and $\beta_{\mathrm{T} 30}$ values indicated a greater affinity with colder sea

259 temperatures, and vice versa. The species fell into one of two groups divided by a line separating

260 warm and cold affinity with slope $=-1$, and intercepts $(0,0)$, and we categorized individuals as

261 cold or warm associated community members accordingly.

262

263

The cold associated group consisted of L. peru, S. lalandi, S. revoliana, and M. jordani.

264 The warm associated group consisted of $C$. caballus, C. hippurus, L. argentriventris, $L$.

novemfasciatus and S. lewini. A third group was represented year-round, as indicated by a nonsignificant negative $\log$ likelihood $(\mathrm{P}>0.05)$. These species consisted of $A$. solandri, $D$. composition of species at EBES clearly differed seasonally, and we refer to three distinctive groups as the 'spring assemblage' (cold), 'fall assemblage' (warm), and 'year-round assemblage'

270 (no significant response to temperature). We refer collectively to all three groups as the

271 seamount-associated community.

272

273 Species curves

To better visualize the seasonal process of species turnover we plotted species seasonal distribution curves (Fig. 5). The resulting curves indicate strong temporal partitioning among the fall and spring assemblages, with some overlap near the distribution tails at the boundaries that occurred during December through February and May through July (Fig. 5A and B). Within assemblages the curves were somewhat offset, but more similar within the spring assemblage 
279 than the fall. Abundance was near zero during warm months for all four spring species (also see

280 Table 4), and the seasonal peaks where more aligned except that $S$. lalandi was shifted slightly

281 earlier than the others. Among fall assemblage members, abundance curves did not overlap as

282 clearly. Some members were absent altogether from the seamount during the colder months,

283 while others were still present in low numbers. For example, C. caballus and C. hippurus were

284 never observed in winter months between January through April and May respectively, while $L$.

285 argentriventris was observed during every month of the year, but peaked in abundance during

286 the warmer periods (see Table 4). Within the year-round assemblage abundance curves were

287 generally less defined in amplitude and peaked at different times (Fig. 5C). Some notable

288 exceptions include $L$. Colorado and $A$. solandri whose curves resemble those of the fall

289 assemblage, and M. rosacea, which resembled the spring assemblage.

290

291 Variation in species richness

292 The pattern of seasonal species turnover lead to variation in the cumulative number

293 species observed during each month ( $\min =8$ and $\max =16$ species). There was a positive linear

294 relationship $(\mathrm{p}=0.004)$ between the number of species and the surface to $30 \mathrm{~m}$ thermal gradient

295 (Fig. 6). There was no significant relationship found between number of species and SST ( $p=$

296 0.139) or T30 $(\mathrm{p}=0.921)$. More species were observed when members of all assemblages

297 overlapped from June through August, a season when greater thermal heterogeneity, warm

298 surface and cool deep water ( $\geq 30 \mathrm{~m})$, characterized the seamount environment (see Fig 1c). 
301 Discussion.

302 Underwater visual censuses are particularly challenging in open water where large

303 schools of rapidly swimming individuals need to be quantified and recorded. The method of log

304 scale ordinal bins presented here provides a simple and accurate way to estimate relative

305 abundance where precision is scaled inversely with sampling difficulty to minimize observer

306 error. The resulting ordinal binning is appropriate for logistic regression; a robust multivariate

307 approach relevant to zero-inflated datasets. The resulting patterns of variation in the composition

308 and number of species provided insights relevant to the processes of shallow seamount fish

309 assemblage. Although the study was confined to a single seamount, the patterns observed over a

310 five-year period were clear and can be evaluated in the context of potential hypotheses

311 explaining elevated predator richness at seamounts.

312

313 Functional similarities in distinct fish assemblages

314 For species that were present year-round, the seamount environment likely fulfills

315 multiple vital life-history functions, including feeding, refuge, and reproduction. However, what

316 specific function does the seamount provide for the spring and fall assemblages? The arrival of

317 certain community members at EBES coincided with reported months of spawning aggregations

318 in the Gulf of California. These included members of both the fall and spring groups. $L$.

319 novemfasciatus generally peaked at EBES near September (see Fig. 3B), which is the reported

320 spawning season for this species in the Gulf of California (Sala et al., 2003). Apart from these

321 peaks in abundance, L. novemfasciatus generally was absent from EBES. Sala et al. (2003) also

322 reported S. lalandi aggregations spawning at reefs and seamounts in April, citing observations of

323 high densities and hydrated eggs in gonads. Peak abundance of S. lalandi at EBES occurred 
324 between January and April (see Fig. 3A). All three female S. lalandi sacrificially sampled in the

325 fishing surveys at EBES during a large aggregation on February 3, 2003 had large gonads with

326 hydrated eggs. A single male captured during this event released milt as it was brought aboard.

327 Thus the arrival of $L$. novemfasciatus and S. lalandi at EBES, although during opposite seasons,

328 were both linked to yearly spawning (Sala et al., 2003). Migrations to site and season-specific

329 spawning aggregations, can be on the order of hundreds of kilometers (Bolden, 2000), could

330 potentially be to find conspecifics or to select environmental conditions favoring larval survival

331 (Johannes 1978).

332

333

Like many seamounts, EBES is a distinct geophysical feature, and is likely to function as

334

a navigational (reference) or meeting (destination) point where wide-ranging organisms come

together for mating events or otherwise. Sphyrna lewini, a member of the fall assemblage,

336

aggregates in large groups at EBES and other seamounts (Klimley \& Nelson, 1984). Previous

337

studies have illustrated their emigration, alone or in small groups, away from EBES to

surrounding open waters at night, presumably to forage, and return to the seamount the following

dawn (Klimley \& Nelson, 1984; Klimley, 1993). While foraging and mating apparently do not

occur at EBES, during the day, the dense schools of hammerhead sharks remained closely

341

associated with EBES slowly swimming back and forth along the ridge. Thus seamounts appear

342

to provide a refuge and spatial reference.

Enriched foraging potential at shallow seamounts is another potential attraction for visitors and may increase their residence time. (Fontenau, 1991) suggested that certain seamounts may enhance foraging by $T$. albacares, and some, but not all seamounts are associated with increased 
347 catch per unit effort of T. albacares and other tuna species (Morato et al., 2010b). At EBES

348 schools of T. albacares were frequently observed feeding (personal observation). Individual

349 tunas tagged with acoustic tags remained resident near EBES at all times of the year for periods

350 ranging from a few days to greater than a year (Klimley et al., 2003). During prolonged

351 residence, the intervals between detections were brief and indicated the tunas could rarely have

352 moved more than $900 \mathrm{~m}$ from EBES. While not all tagged T. albacares resided at the seamount,

353 those that did likely foraged in close association with EBES over extended periods. In addition to

354 foraging, seamounts also may play a role in navigation for T. albacares (Holland, Kleiber \&

355 Kajiura, 1999), which could explain why some tuna remained resident while others did not

356 (Klimley et al., 2003).

357

358

359

360

361

362

363

364

365

366

367

368

369

370

From these observations of just some of the assemblage members, it seems clear that

pelagic and reef-associated fishes (see Table 1) co-occur at EBES to fulfill a variety of functions including foraging, spawning and navigation. These and possibly other drivers attracted seamount visitors during a range of seasonally varying environmental conditions. There was a large range in the overall temperature and water column thermal structure (Figs. 1 and 2). Yet spawning, foraging, and navigation occurred at various times throughout the year (e.g. spawning by fall and spring assemblage members) despite the contrasting environmental conditions.

\section{Assemblage cohesion}

Our data reveal how local seamount communities are ephemeral and structurally dependent on seasonal and regional oceanographic conditions. At EBES distinct assemblages were evident associated with pronounced seasonal changes in oceanography. Many pelagic fish species, such as tunas, track thermal fronts and other oceanographic features (Laurs, Yuen \& 
371 Johnson, 1977; Kitagawa et al., 2007; Schaefer, Fuller \& Block, 2007) and reside for extended

372 periods around seamounts (Holland, Kleiber \& Kajiura, 1999; Klimley et al., 2003). Thus, the

373 movement of oceanographic features over seamounts may determine the pool of species

374 available at a given time and the composition of seamount-associated communities.

375

376

377

378

379

380

381

382

383

384

385

386

387

388

389

390

391

392

393

394

395

396

(Klimley \& Butler, 1988) hypothesized that some fish species groups may occur as 'mobile communities' in the open ocean arriving and departing from local seamounts as a single unit. We were unable to track the precise arrival and departure timing of assemblage members, however, a number of results suggest that members converged at EBES under slightly different conditions, and for different purposes. Ordination analysis clearly grouped overall warm associated species distinctly from the cold associated group (see Fig. 4). Within these groups, however, further structure was evident. For example, in the fall assemblage, C. caballus abundance was highly correlated with warmer SST, but also negatively correlated with T30 (Fig 4; Table S1); conditions that prevail in summer. In contrast S. lewini abundance was highly positively correlated with warmer T30, but negatively correlated with warmer SST (Fig. 4; Table S1); typical fall conditions (Figs. 1 and 2). This structure was further evident in the offset of abundance curve peaks between C. caballus in August, and S. lewini in November (Fig. 5a). The remaining fall assemblage members peaked in abundance somewhere between these two (Figs. 4 and 5). Similar structure, although more subtle, occurred for the spring assemblage. This general offset in peak relative abundance suggests that members likely did not arrive together. Furthermore, within the fall assemblage, some species were present at EBES in low abundance year-round during the off-peak seasons (e.g. L. argentiventris) while others were completely absent when not in peak abundance (e.g. C. caballus). Finally, within-assemblage differences in the nature of each species association with the seamount (e.g L. novemfasciatus gathered to spawn, while S. lewini aggregated at EBES during daylight and foraged away at 
397 night) suggest that at least some members co-occurred at the seamount for dissimilar reasons.

398 We conclude that assembly of seamount community members at EBES was largely the result of

399 'species-individualistic' processes. The associations between aggregating species were

400 seasonally ephemeral, and likely confined to this place and time. Once aggregated at the

401 seamount, however, it seems possible that sudden movements of water masses, on short time

402 scales, might influence an entire assemblage, away from or back to a seamount (Klimley \&

403 Butler, 1988).

404

405 Species richness

406 Water temperature is a strong predictor for species richness among broad marine taxa; for

407 open ocean fishes and foraminifera this convex function peaks near $25^{\circ} \mathrm{C}$ (Rutherford, D'Hondt

408 \& Prell, 1999; Worm et al., 2005; Whitehead, McGill \& Worm, 2008) and at corresponding

409 intermediate latitudes (Morato et al., 2010a). The mean SST at EBES was $25.4^{\circ} \mathrm{C}$ and ranged

410 seasonally from 18 to $30^{\circ} \mathrm{C}$. Given the movement potential of the seamount-associated species

411 and the prevalence of seasonally advancing and retreating thermal fronts ((Klimley \& Butler,

412 1988; Trasvina-Castro et al., 2003; Douglas et al., 2007); Fig. 1), one might predict that the

413 greatest number of species would occur at EBES when temperature were near $25^{\circ} \mathrm{C}$. A mean

$414 \mathrm{SST}$ of $25^{\circ} \mathrm{C}$ occurred twice each year at EBES; during summer (May) and late fall (November)

415 transitions respectively (Fig. 1). However, increased predator richness at the seamount was not

416 predictable by surface temperature alone. Instead, it was correlated with greater vertical thermal

417 gradient. Interestingly, the strongest gradients occurred in summer and the weakest in late fall. In

418 essence increased species richness did occur when surface temperature was near $25^{\circ} \mathrm{C}$, but only

419 during summer when processes occurring below the surface where the likely drivers. 
422 after the average peak in abundance of the spring assemblage (March) and before that of the fall 423 assemblage (September); apparently not the prime 'target' period for either group. That species

424 co-occurred for a number of different functions also suggests that it was not linked to a single

425 prevalent environmental state. In fact the highest variability in temperature, both temporally and 426 spatially (i.e. in the water column), occurred then, suggesting increased habitat heterogeneity 427 itself is likely to be an important factor. Summer is a warming transition period at EBES when warm and cold water occurs simultaneously providing a thermally heterogeneous habitat. This range of temperatures, accessible across a narrow range of depths, may accommodate the thermal optima (Blank et al., 2002; Boyce, Tittensor \& Worm, 2008) of a wider range of species thereby enabling the co-occurrence of both fall and spring assemblages. Globally, over broad spatial and temporal scales, pelagic tuna and billfish diversity positively correlates with spatial temperature (SST) gradient, and where data are available, tuna and billfish diversity correlates in

434 turn with total predator diversity (Worm et al., 2005). scale and may also shape patterns of diversity of vagile ocean fishes at larger scales. The 
444 foraging opportunities may increase species richness via the 'species-energy' hypothesis (Worm,

445 Lotze \& Myers, 2003; McClain, 2007; Morato et al., 2010a). What can seasonal variation at

446 EBES tell us about a trophic link to observed changes in species richness? Local food supply

447 could be augmented, either through vertical mixing and elevated primary productivity, or

448 through concentration of macroplankton (Wolanski \& Hamner, 1988; Genin, 2004). It is unlikely

449 that the residence time of upwelled water around seamounts is sufficiently long for primary

450 production enrichment to propagate up the food web to the level of predatory fishes (Genin,

451 2004). However, a match between enhanced primary productivity and early life-history survival

452 (Cushing, 1990) could increase larvae fitness for fishes spawning at seamounts whether water

453 masses (including nascent larvae) were advected or retained. That at least two species aggregated

454 at EBES to spawn suggests enhanced primary production at seamounts could be one mechanism

455 for increasing predator fish richness that is not directly related to the 'species-energy' model.

Primary productivity in the Gulf of California is typically highest during fall/winter, when strong winds drive regional upwelling, and lowest in spring/summer (Douglas et al., 2007). However, another important mechanism for primary productivity in the Gulf is tidally driven vertical mixing (Trasvina-Castro et al., 2003; Douglas et al., 2007). At EBES dynamic instability

461 and mixing due to vertical current sheer occur over the top of the seamount (Trasvina-Castro et

462 al., 2003; Douglas et al., 2007). Vertical mixing at this depth would likely be drowned out in

463 fall/winter when the mixed layer typically extends well below $50 \mathrm{~m}$ (Fig. 2) but may become

464 locally important during spring/summer when the thermocline is shallow and wind driven

465 production is regionally limiting. 
The most widely accepted mechanism for enhanced foraging at seamounts involves a

468 biophysical match between currents and animal behavior (Genin, 2004; McClain, 2007).

469 However, quantifying prey (zooplankton) availability was beyond the scope of this study. While

470 this mechanism cannot therefore be directly addressed as a contributing factor for increased

471 richness, two observations suggest it may not be the primary driver at EBES. First, many species

472 arrived at the seamount for reasons other than foraging. Second, the summer period, when the

473 greatest number of species was observed, appeared to be a 'transition' period rather than a

474 'target' period for either fall or spring assemblages. If foraging were the primary common driver

475 explaining increased richness during summer, then one might expect more species to coincide in 476 their peak abundance.

Ultimately these observations are also more consistent with the 'habitat heterogeneity'

hypothesis since fish species occurred at EBES for a variety of functions including foraging, spatial reference and reproduction during different seasons. The intra-annual turnover of species, or temporal beta-diversity resulted in seasonal variation in fish species numbers at EBES that was positively correlated with thermal heterogeneity in the water column. Although this study was limited to a single seamount location, the UVC methods and clear patterns observed enable comparisons to other locations, and in this case provide support for the idea that oceanographically heterogeneous and dynamic seamounts may support greater predator richness.

\section{Acknowledgements.}

Considerable logistical support was provided by H. Fastenau, L. Inman, F. McLeese, M.

489 Cota, J. Richert, J. Downs, I. Nevius, M. Silva, numerous staff of Centro de Invesigaciones 
490 Biologicas del Baja Norte of La Paz, and the Cortez Club. We also thank C. Logan for helpful 491 review and comments on the manuscript.

492

493 


\section{References.}

495

496

497

498

499

500

501

502

503

504

505

506

507

508

509

510

511

512

513

514

515

516

Blank J., Morrissette J., Davie P., Block B. 2002. Effects of temperature, epinephrine and Ca2+ on the hearts of yellowfin tuna (Thunnus albacares). Journal of Experimental Biology 205:1881-1888.

Bolden S. 2000. Long-distance movement of a Nassau grouper (Epinephelus striatus) to a spawning aggregation in the central Bahamas. Fishery Bulletin 98:642-645.

Boyce DG., Tittensor DP., Worm B. 2008. Effects of temperature on global patterns of tuna and billfish richness. Marine Ecology Progress Series 355:267-276. DOI: $10.3354 / \operatorname{meps} 07237$

Clark MR., Rowden AA., Schlacher T., Williams A., Consalvey M., Stocks KI., Rogers AD., O’Hara TD., White M., Shank TM., Hall-Spencer JM. 2010. The Ecology of Seamounts: Structure, Function, and Human Impacts. Annual Review of Marine Science 2:253-278. DOI: 10.1146/annurev-marine-120308-081109.

Clark MR., Schlacher TA., Rowden AA., Stocks KI., Consalvey M. 2012. Science Priorities for Seamounts: Research Links to Conservation and Management. PLOS ONE 7:e29232. DOI: 10.1371/journal.pone.0029232.

Cushing D. 1990. Plankton production and year-class strength in fish populations - an update of the match mismatch hypothesis. Advances in Marine Biology 26:249-293.

Douglas R., Gonzalez-Yajimovich O., Ledesma-Vazquez J., Staines-Urias F. 2007. Climate forcing, primary production and the distribution of Holocene biogenic sediments in the Gulf of California. Quartenary Science Reviews 26:115-129. DOI: 10.1016/j.quascirev.2006.05.003. 
517 Fontenau A. 1991. Seamounts and tuna in the tropical Atlantic. Aquatic Living Resources 4:13$518 \quad 25$.

519 Freon P., Dagorn L. 2000. Review of fish associative behaviour: toward a generalisation of the 520 meeting point hypothesis. Reviews in Fish Biology and Fishes 10:183-207.

521 Genin A. 2004. Bio-physical coupling in the formation of zooplankton and fish aggregations over abrupt topographies. Journal of Marine Systems 50:3-20. DOI:

523 10.1016/j.marsys.2003.10.008.

524 Holland KN., Grubbs RD. 2007. Fish Visitors to Seamounts: Tunas and Bill Fish at Seamounts.

525

526

527

528

530

531

532

533

534

535

536

537

538

In: Pitcher TJ, Morato T, Hart PJB, Clark lcolm R, Haggan N, Santos RS eds. Seamounts: Ecology, Fisheries \& Conservation. Blackwell Publishing Ltd, 189-201.

Holland KN., Kleiber P., Kajiura SM. 1999. Different residence times of yellowfin tuna, Thunnus albacares, and bigeye tuna, T-obesus, found in mixed aggregations over a seamount. Fishery Bulletin 97:392-395.

Hubbs CL. 1959. Initial Discoveries of Fish Faunas on Seamounts and Offshore Banks in the Eastern Pacific.

Jorgensen SJ., Klimley AP., Muhlia-Melo AF. 2009. Scalloped hammerhead shark Sphyrna lewini, utilizes deep-water, hypoxic zone in the Gulf of California. Journal of Fish Biology 74:1682-1687. DOI: 10.1111/j.1095-8649.2009.02230.x.

Kitagawa T., Boustany A., Farwell C., Williams T., Castleton M., Block B. 2007. Horizontal and vertical movements of juvenile bluefin tuna (Thunnus orientalis) in relation to seasons and oceanographic conditions in the eastern Pacific Ocean. Fisheries Oceanography 16:409-421. DOI: 10.1111/j.1365-2419.2007.00441.x. 
539 Klimley AP. 1993. Highly Directional Swimming by Scalloped Hammerhead Sharks, Sphyrna

$540 \quad$ lewini, and Subsurface Irradiance, Temperature, Bathymetry, and Geomagnetic-Field.

$541 \quad$ Marine Biology 117:1-22.

542 Klimley AP., Jorgensen SJ., Muhlia-Melo A., Beavers SC. 2003. The occurrence of yellowfin tuna (Thunnus albacares) at Espiritu Santo Seamount in the Gulf of California. Fishery Bulletin 101:684-692.

545 Klimley AP., Butler S. 1988. Immigration and emigration of a pelagic fish assemblage to seamounts in the Gulf of California related to water mass movements using satellite imagery. Marine Ecology-Progress Series 49:11-20.

Klimley AP., Nelson DR. 1984. Diel movement patterns of the scalloped hammerhead shark (Sphyrna lewini) in relation to El Bajo Espiritu Santo: a refuging central-position social system. Behavioral Ecology and Sociobiology 15:45-54.

551 Kvile KØ., Taranto GH., Pitcher TJ., Morato T. 2014. A global assessment of seamount 552 ecosystems knowledge using an ecosystem evaluation framework. Biological Conservation 173:108-120. DOI: 10.1016/j.biocon.2013.10.002.

554 Laurs RM., Yuen HSH., Johnson JH. 1977. Small-scale movements of albacore, Thunnus alalunga, in relation to ocean features as indicated by ultrasonic tracking and oceanographic sampling. Fishery Bulletin 75(2)1607:347-355.

557 Litvinov F. 2007. Fish Visitors to Seamounts: Aggregations of Large Pelagic Sharks Above Seamounts. In: Pitcher TJ, Morato T, Hart PJB, Clark lcolm R, Haggan N, Santos RS eds. Seamounts: Ecology, Fisheries \& Conservation. Blackwell Publishing Ltd, 202-206.

560 Lueck RG., Mudge TD. 1997. Topographically Induced Mixing Around a Shallow Seamount. Science 276:1831-1833. DOI: 10.1126/science.276.5320.1831. 
562 McClain C. 2007. Seamounts: identity crisis or split personality? Journal of Biogeography

563 34:2001-2008. DOI: 10.1111/j.1365-2699.2007.01783.x.

564 McClain CR., Lundsten L. 2015. Assemblage structure is related to slope and depth on a deep 565 offshore Pacific seamount chain. Marine Ecology 36:210-220. DOI:

566 10.1111/maec. 12136 .

\section{7}

568

Morato T., Varkey D., Damaso C., Machete M., Santos M., Prieto R., Santos R., Pitcher T. 2008.

Morato T., Hoyle SD., Allain V., Nicol SJ. 2010b. Tuna Longline Fishing around West and

Morato T., Hoyle SD., Allain V., Nicol SJ. 2010a. Seamounts are hotspots of pelagic Evidence of a seamount effect on aggregating visitors. Marine Ecology-Progress Series

Morato T., Miller PI., Dunn DC., Nicol SJ., Bowcott J., Halpin PN. 2015. A perspective on the importance of oceanic fronts in promoting aggregation of visitors to seamounts. Fish and Fisheries:n/a-n/a. DOI: 10.1111/faf.12126.

Morato T., Clark MR. 2007. Seamount Fishes: Ecology and Life Histories. In: Pitcher TJ, Morato T, Hart PJB, Clark lcolm R, Haggan N, Santos RS eds. Seamounts: Ecology, Fisheries \& Conservation. Blackwell Publishing Ltd, 170-188.

581 Rogers AD. 1994. The biology of seamounts. Advances in Marine Biology 30:305-305.

582 Rutherford S., D’Hondt S., Prell W. 1999. Environmental controls on the geographic distribution 583 of zooplankton diversity. Nature 400:749-753. 
584 Sala E., Aburto-Oropeza O., Paredes G., Thompson G. 2003. Spawning aggregations and 585 reproductive behavior of reef fishes in the Gulf of California. Bulletin of Marine Science $586 \quad 72: 103-121$.

587 Schaefer K., Fuller D., Block B. 2007. Movements, behavior, and habitat utilization of yellowfin 588 tuna (Thunnus albacares) in the northeastern Pacific Ocean, ascertained through archival tag data. Marine Biology 152:503-525. DOI: 10.1007/s00227-007-0689-x.

590

591

592

593

594

595

596

597

598

599

600

601

602

603

604

605

Staudigel H., Koppers A., Lavelle JW., Pitcher T., Shank T. 2010. Defining the Word “Seamount.” Oceanography 23:20-21. DOI: 10.5670/oceanog.2010.85.

Trasvina-Castro A., de Velasco GG., Valle-Levinson A., Gonzalez-Armas R., Muhlia A., Cosio MA. 2003. Hydrographic observations of the flow in the vicinity of a shallow seamount top in the Gulf of California. Estuarine Coastal and Shelf Science 57:149-162.

Whitehead H., McGill B., Worm B. 2008. Diversity of deep-water cetaceans in relation to temperature: implications for ocean warming. Ecology Letters 11:1198-1207. DOI: 10.1111/j.1461-0248.2008.01234.x.

Wolanski E., Hamner WM. 1988. Topographically Controlled Fronts in the Ocean and Their Biological Influence. Science 241:177-181.

Worm B., Sandow M., Oschlies A., Lotze H., Myers R. 2005. Global patterns of predator diversity in the open oceans. Science 309:1365-1369. DOI: 10.1126/science.1113399.

Worm B., Lotze H., Myers R. 2003. Predator diversity hotspots in the blue ocean. Proceedings of the National Academy of Sciences 100:9884-9888. DOI: 10.1073/pnas.1333941100.

Wright DH. 1983. Species-energy theory: an extension of species-area theory. Oikos:496-506. 
607 Tables.

608

609

610

611

612

613

614

615

616

617

618

619

620

621

622

623

624

625

626

627

628

629

630

631

632

633

634

635

636

637

638

639

640

641

642

643

644

645

646

647

648

649

650

651

652

653

654

655

Table 1. List of fish species observed during underwater visual censuses at Espiritu Santo Seamount (EBES).

\begin{tabular}{|c|c|c|c|}
\hline Family or Class & Common Name & Species & Environment* \\
\hline Carangidae & $\begin{array}{l}\text { Green jack } \\
\text { Jack mackerel } \\
\text { Mackerel scad } \\
\text { Yellowtail } \\
\text { Amberjack } \\
\text { Gafftopsail pompano }\end{array}$ & $\begin{array}{l}\text { Caranx caballus } \\
\text { Trachurus symmetricus } \\
\text { Decapterus macarellus } \\
\text { Seriola lalandi } \\
\text { Seriola rivoliana } \\
\text { Trachinotus rhodopus }\end{array}$ & $\begin{array}{l}\text { Pelagic-neritic } \\
\text { Pelagic-oceanic } \\
\text { Pelagic-oceanic } \\
\text { Benthopelagic } \\
\text { Reef-associated } \\
\text { Reef-associated }\end{array}$ \\
\hline Chondrichthyes & $\begin{array}{l}\text { Hammerhead shark } \\
\text { Silky shark } \\
\text { Whale shark } \\
\text { Manta }\end{array}$ & $\begin{array}{l}\text { Sphyrna lewini } \\
\text { Carcharhinus falciformis } \\
\text { Rhincodon typus } \\
\text { Manta hamiltoni }\end{array}$ & $\begin{array}{l}\text { Pelagic-oceanic } \\
\text { Reef-associated } \\
\text { Pelagic-oceanic } \\
\text { Reef-associated }\end{array}$ \\
\hline Coryphaenidae & Dorado & Coryphaena hippurus & Pelagic-neritic \\
\hline Istiophoridae & $\begin{array}{l}\text { Sailfish } \\
\text { Striped marlin } \\
\text { Blue marlin }\end{array}$ & $\begin{array}{l}\text { Istiophorus platypterus } \\
\text { Tetrapterus audax } \\
\text { Makaira mazara }\end{array}$ & $\begin{array}{l}\text { Pelagic-oceanic } \\
\text { Pelagic-oceanic } \\
\text { Pelagic-oceanic }\end{array}$ \\
\hline Lutjanidae & $\begin{array}{l}\text { Red snapper } \\
\text { Yellow snapper } \\
\text { Mullet snapper } \\
\text { Dog snapper } \\
\text { Colorado snapper } \\
\text { Barred snapper } \\
\text { Rose-spotted snapper }\end{array}$ & $\begin{array}{l}\text { Lutjanus peru } \\
\text { Lutjanus argentriventris } \\
\text { Lutjanus aratus } \\
\text { Lutjanus novenfasciatus } \\
\text { Lutjanus colorado } \\
\text { Hoplopagrus guntherii } \\
\text { Lutjanus guttatus }\end{array}$ & $\begin{array}{l}\text { Reef-associated } \\
\text { Reef-associated } \\
\text { Reef-associated } \\
\text { Reef-associated } \\
\text { Reef-associated } \\
\text { Reef-associated } \\
\text { Reef-associated }\end{array}$ \\
\hline Scombridae & $\begin{array}{l}\text { Yellowfin tuna } \\
\text { Black skipjack } \\
\text { Wahoo }\end{array}$ & $\begin{array}{l}\text { Thunnus albacares } \\
\text { Euthynnus lineatus } \\
\text { Acanthocybium solandri }\end{array}$ & $\begin{array}{l}\text { Pelagic-oceanic } \\
\text { Pelagic-oceanic } \\
\text { Pelagic-oceanic }\end{array}$ \\
\hline Serranidae & $\begin{array}{l}\text { Creolfish } \\
\text { Gulf grouper } \\
\text { Leopard grouper }\end{array}$ & $\begin{array}{l}\text { Paranthias colonus } \\
\text { Mycteroperca jordani } \\
\text { Mycteroperca rosacea }\end{array}$ & $\begin{array}{l}\text { Reef-associated } \\
\text { Reef-associated } \\
\text { Reef-associated }\end{array}$ \\
\hline
\end{tabular}

\footnotetext{
*Environment classification from FishBase (www.fishbase.org).
} 
656

657

658 Table 2. The bin centers and ranges corresponding to

659 ordinal scores for underwater visual census counts.

660 Repeated censuses were averaged and then assigned

661 ordinal scores according to the following $\log _{2}$

662 classification scheme.

663

664

665

666

667

668

669

670

671

672

673

674

675

676

677

678

679

680

681

682 
683

684

685

686

687

688

689

690

691

692

693
694

695

696

697

698

699

700

701

702

Table 3. Ordinal values from underwater visual counts of fishes at El Bajo Espiritu seamount from 1999-2004 by month. Each value represents the mean number of individuals counted per number of transects. nd indicates no data.

\begin{tabular}{|c|c|c|c|c|c|c|c|c|c|c|c|c|c|c|c|c|c|c|c|c|c|c|c|c|c|c|}
\hline & \multicolumn{3}{|c|}{1999} & \multicolumn{4}{|c|}{2000} & \multicolumn{2}{|c|}{2001} & \multicolumn{6}{|c|}{2002} & \multicolumn{5}{|c|}{2003} & \multicolumn{6}{|c|}{2004} \\
\hline & May & $\mathrm{Aus}$ & $\mathrm{Nov}$ & Feb & Apr & Jun & Sep & Mar & Jul & Jun & Jul & Sep & Oct & Nov & Dec & Feb & Mar & May & Oct & Nov & Jan & Apr & May & Jun & Jul & Aug \\
\hline Caranx caballus & 0 & 8 & 8 & 0 & 0 & 8 & 8 & 0 & 8 & 7 & 0 & 7 & 6 & 4 & 4 & 0 & 0 & 0 & 1 & 5 & 0 & 0 & 8 & 8 & 8 & 8 \\
\hline Decapterus macarellus & 8 & 8 & 8 & 7 & 7 & 8 & 8 & 7 & 8 & 7 & 6 & 6 & 6 & 7 & 8 & 0 & 7 & 8 & 7 & 8 & 8 & 8 & 8 & 8 & 8 & 7 \\
\hline Euthynnus lineatus & 8 & 8 & 8 & 7 & 2 & 6 & 0 & 6 & 7 & 6 & 4 & 8 & 0 & 0 & 0 & 0 & 4 & 8 & 0 & 7 & 0 & 7 & 8 & 0 & 8 & 2 \\
\hline Lutjanus argentriventris & 8 & 8 & 7 & 1 & 7 & 7 & 7 & 7 & 4 & 4 & 6 & 7 & 8 & 5 & 8 & 4 & 5 & 0 & 8 & 7 & 5 & 8 & 8 & 8 & 8 & 7 \\
\hline Hoplopagrus guntherii & 4 & 4 & 4 & 0 & 4 & 0 & 4 & 2 & 0 & 0 & 0 & 2 & 5 & 0 & 1 & 3 & 3 & 1 & 2 & 3 & 2 & 1 & 4 & 1 & 3 & 3 \\
\hline Lutjanus novemfasciatus & 0 & 5 & 3 & 0 & 0 & 0 & 8 & 0 & 1 & 0 & 0 & 5 & 0 & 0 & 0 & 0 & 0 & 0 & 1 & 4 & 1 & 1 & 0 & 0 & 0 & 0 \\
\hline Lutjanus peru & 8 & 2 & 0 & 7 & 8 & 0 & 0 & 7 & 6 & 6 & 7 & 0 & 0 & 0 & 0 & 0 & 0 & 8 & 0 & 0 & 0 & 1 & 8 & 2 & 3 & 0 \\
\hline Mycteroperca jordani & nd & nd & nd & 3 & 2 & 3 & 0 & 2 & 0 & 1 & 1 & 0 & 0 & 0 & 0 & 0 & 1 & 0 & 0 & 0 & 0 & 1 & 0 & 0 & 0 & 0 \\
\hline Mycteroperca rosacea & nd & nd & nd & nd & 3 & 0 & 0 & 4 & 3 & 3 & 1 & 2 & 3 & 3 & 2 & 2 & 3 & 3 & 2 & 3 & 3 & 1 & 4 & 2 & 4 & 0 \\
\hline Paranthias colonus & 8 & 8 & 8 & 8 & 8 & 8 & 8 & 8 & 8 & 8 & 8 & 8 & 8 & 8 & 8 & 8 & 7 & 8 & 8 & 8 & 8 & 8 & 8 & 8 & 0 & 7 \\
\hline Seriola lalandi & 0 & 0 & 0 & 4 & 3 & 0 & 0 & 3 & 0 & 1 & 0 & 0 & 0 & 0 & 0 & 4 & 3 & 0 & 0 & 0 & 4 & 0 & 0 & 0 & 1 & 0 \\
\hline Seriola rivoliana & 4 & 1 & 0 & 4 & 0 & 2 & 0 & 4 & 3 & 2 & 1 & 0 & 0 & 0 & 0 & 0 & 2 & 4 & 0 & 0 & 2 & 2 & 1 & 1 & 0 & 0 \\
\hline Number of replicates & 2 & 2 & 2 & 2 & 2 & 1 & 1 & 4 & 2 & 4 & 2 & 2 & 2 & 3 & 2 & 2 & 2 & 2 & 1 & 2 & 2 & 2 & 1 & 2 & 2 & 2 \\
\hline
\end{tabular}


711 Table 4. Presence or absence of species from both dive and fishing surveys observed by month. 712 Species were given a positive score $(\bullet)$ if they were ever observed during the month over the 5713 year study period.

714

715

716

717

718

719

720

721

722

723

724

725

726

727

728

729

730

731

732

733

734

735

736

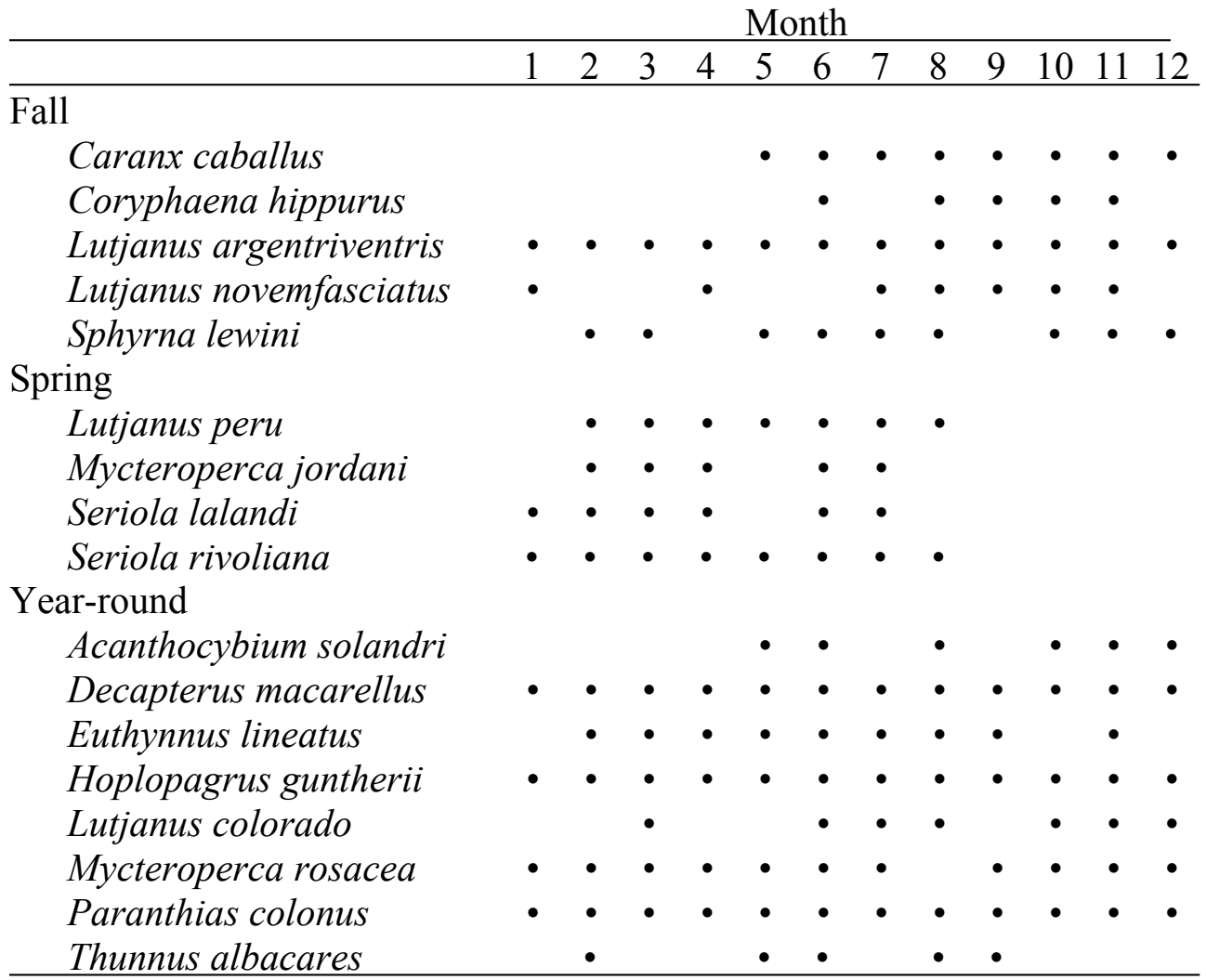

737 
Figures.

739

740 Fig. 1 Map of the Southern Gulf of California and Eastern Pacific Ocean overlain with NOAA

741 AVHRR sea surface temperature (SST). Images from (A) February 4, 2004, and (B) August 2,

7422003 recorded respectively during seasonal high and low peaks of the annual temperature cycle.

743 (C) Sea surface temperature (gray line) and subsurface temperature (black line), measured at a

744 depth of 30 m (T30), at El Bajo Espiritu Santo seamount (EBES; see filled circle in panel A).

745
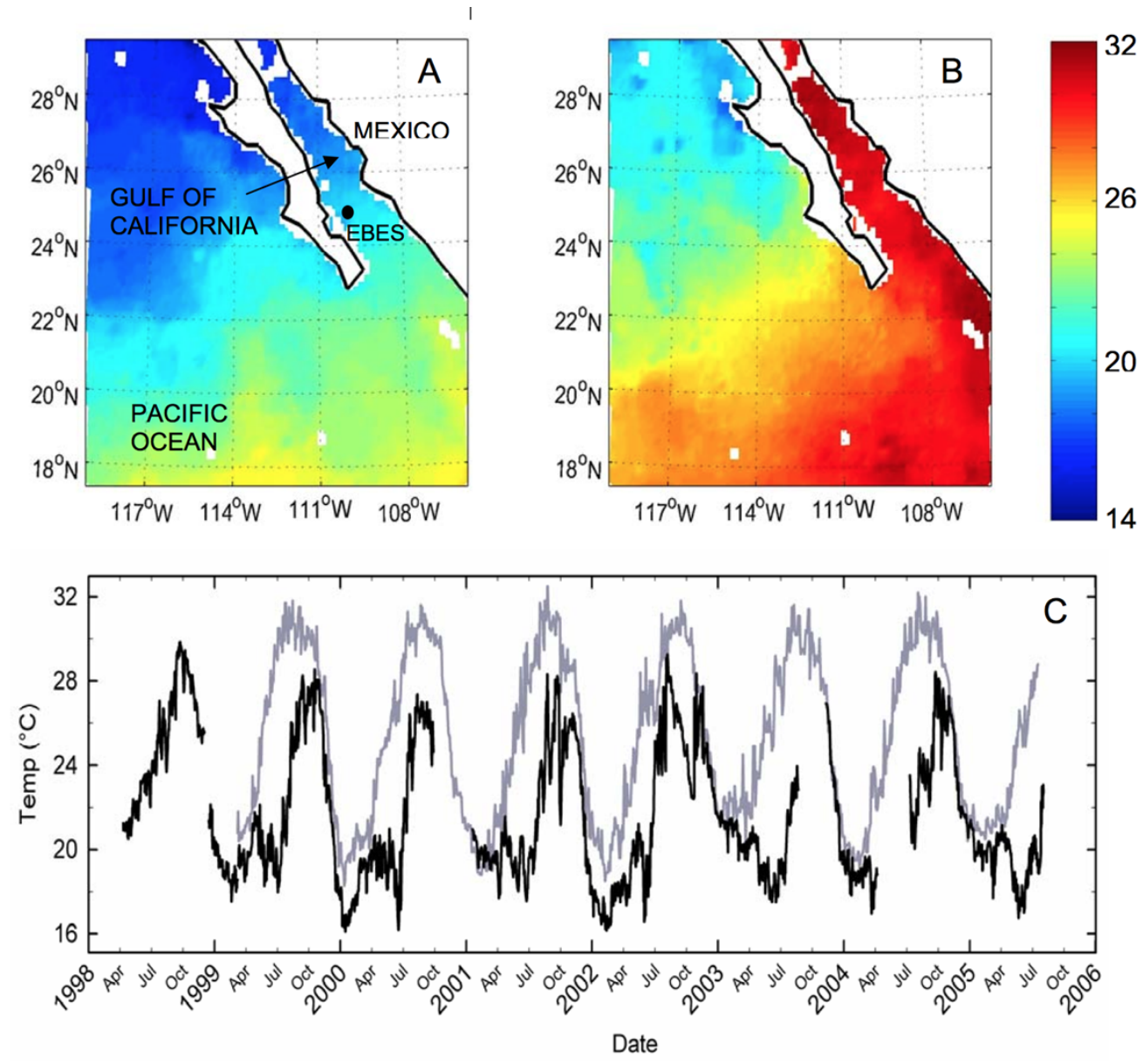

746 
748

749 Fig. 2 Water column profiles of temperature immediately adjacent to El Bajo Espiritu Santo

750 seamount. Stratification above $30 \mathrm{~m}$ (dashed line) ranged from strong in June to very weak in

751 November.

752

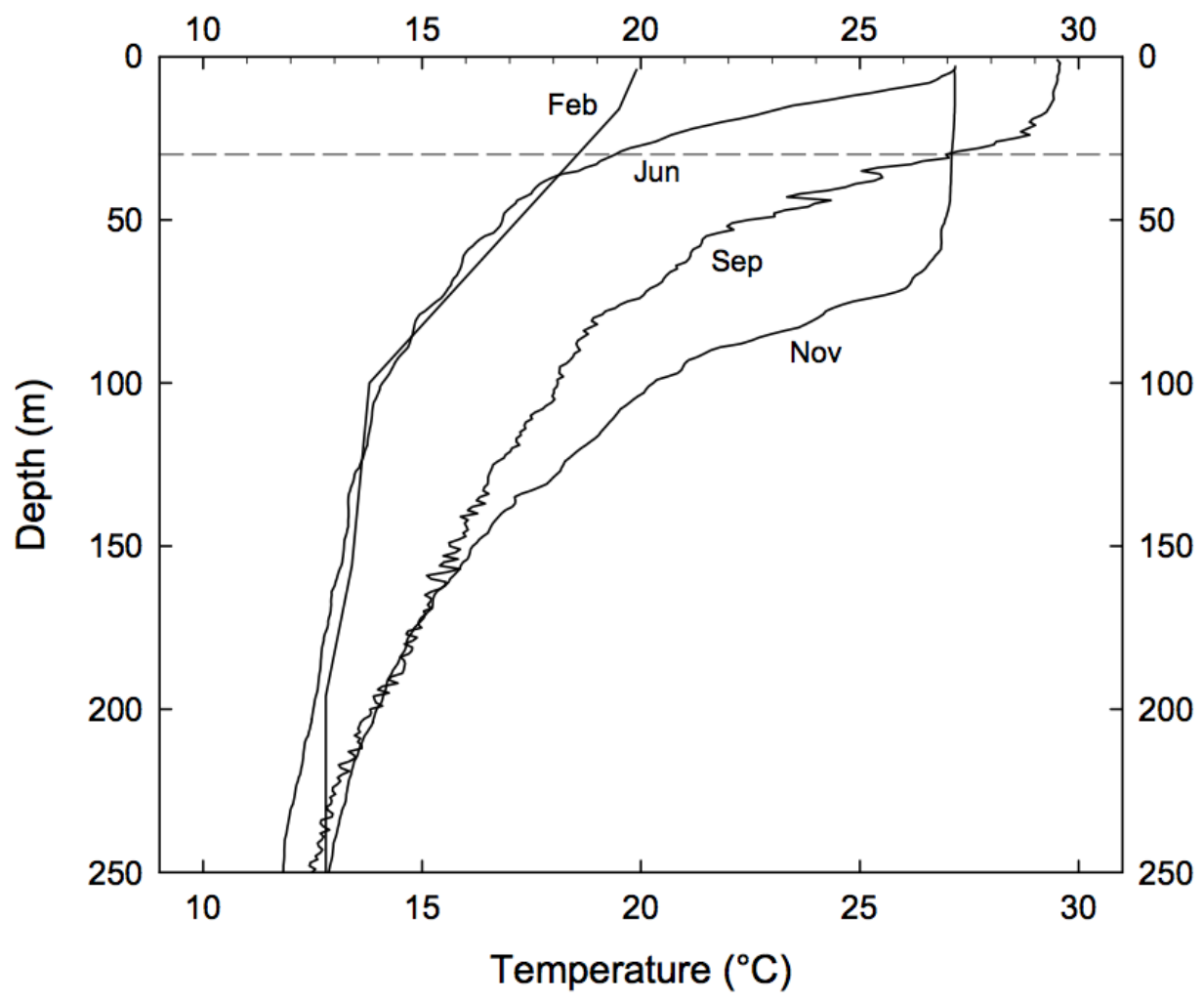

753

754 
755 Fig. 3 Relative abundance of representative species. Illustrative examples from the spring (A)

756

757

758

759

760 Seriola lalandi and fall (B) Lutjanus novemfasciatus assemblages of fishes relative to mean monthly SST (gray line) and T30 (dark line) at El Bajo Espiritu Santo seamount from 19992005. Note that broken line portions in the T30 series represent estimated values for missing data.

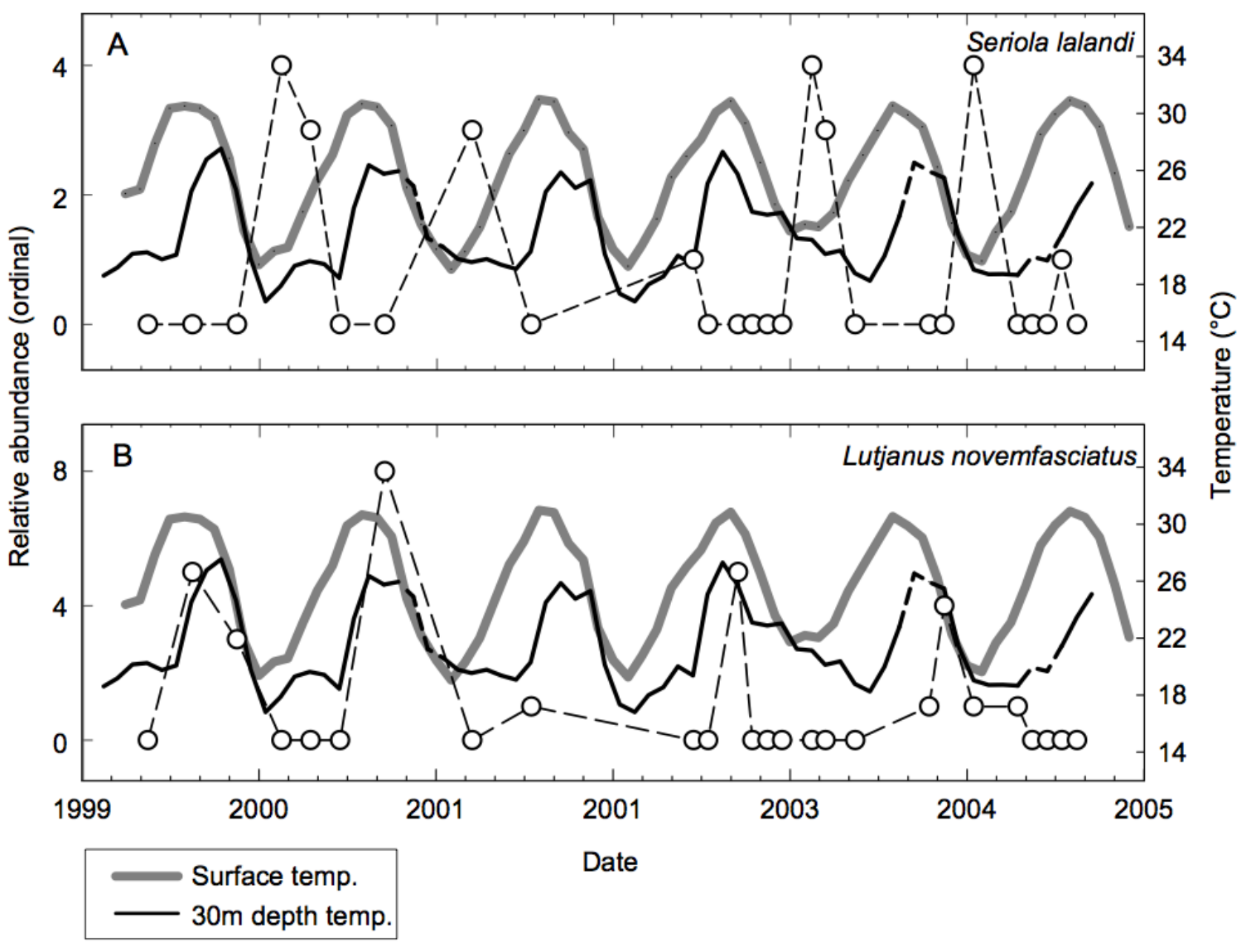

762 
764 Fig. 4 Ordination analysis of seamount fish species assemblages. Negative log likelihood

765 parameter estimates of the two regressors, sea surface temperature (SST) and temperature at 30

$766 \mathrm{~m}(\mathrm{~T} 30)$, from logistic regression plotted on the plane $\gamma=\rho+\beta+\mathrm{SST}+\beta \mathrm{T} 30$ revealed a spring

767 (upper right) and fall (lower left) assemblage. Error bars represent standard error. Dark circles

768 resulted from ordinal regression, and open circle resulted from nominal regression.

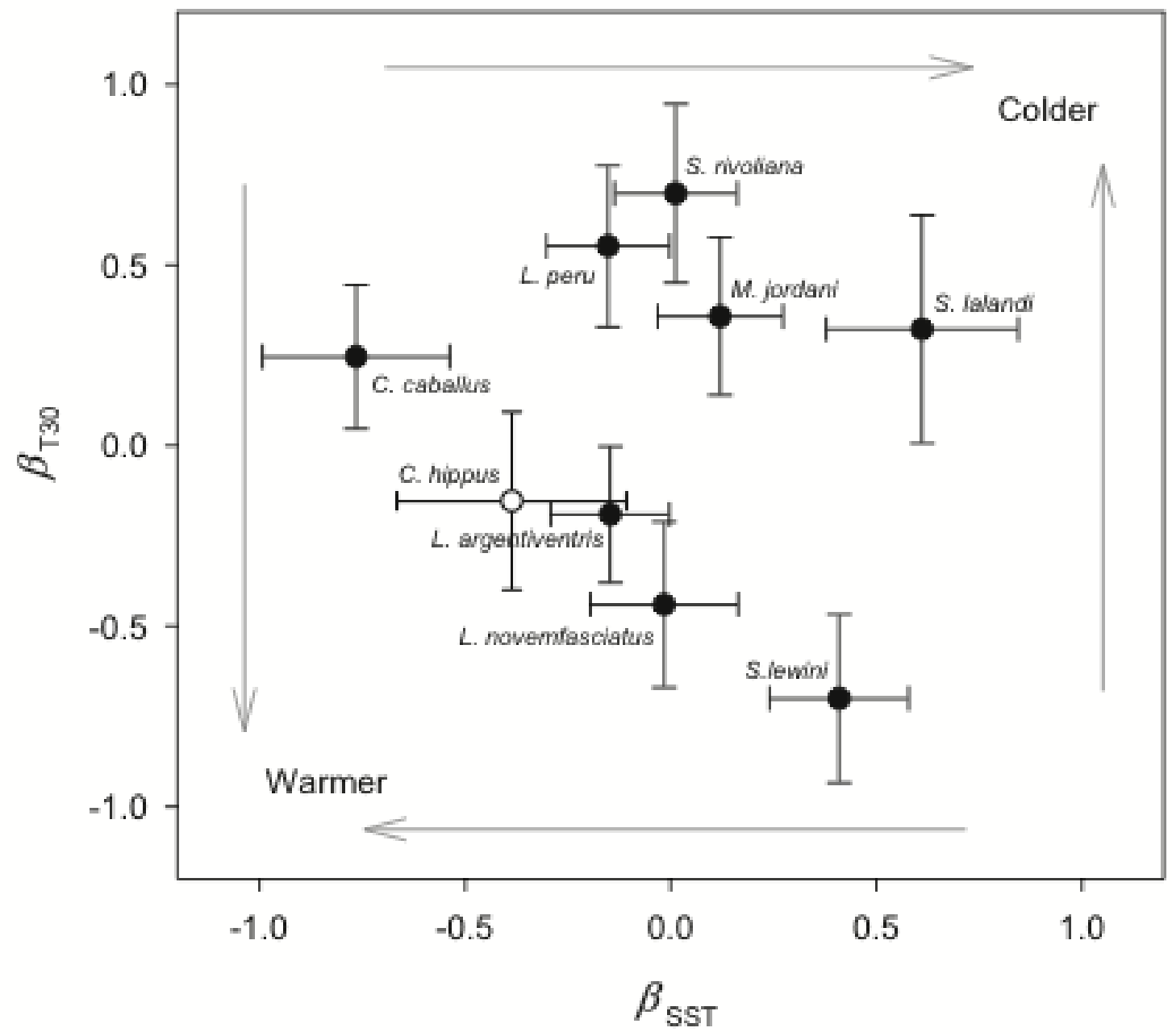

769

770 
772 Fig. 5 Species abundance curves over time. These qualitatively illustrate the occurrence of

773

774

775

776

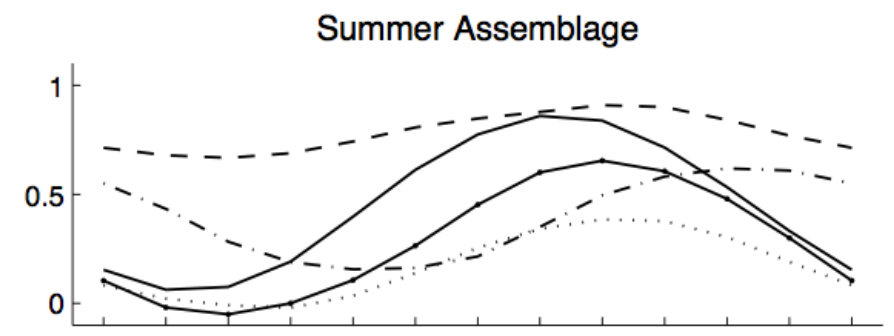

Winter Assemblage
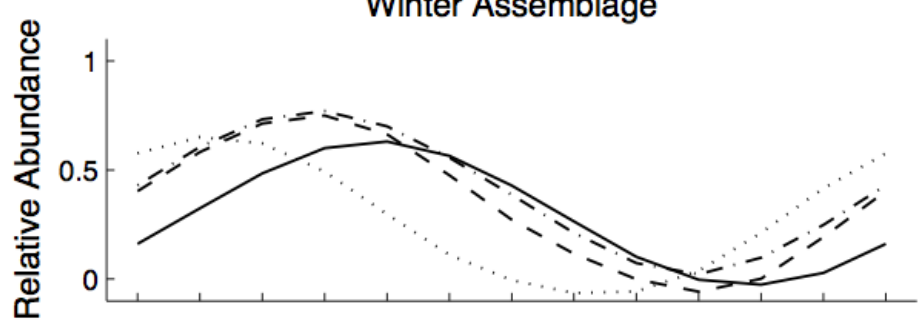

Year-round Assemblage

777

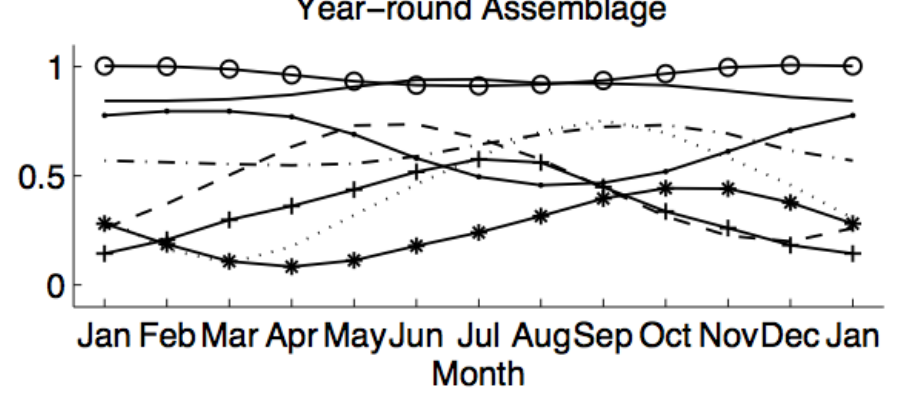

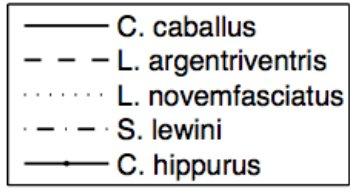

L. peru

- - M. jordani

S. lalandi

$-\cdot$ S. rivoliana

778 
779 Fig. 6 Linear relationship between number of species and vertical thermal gradient at El Bajo

780 Espiritu Santo seamount. The number of observed species increased in months with greater

781 stratification ( $\mathrm{n}=12$ months, $\left.\mathrm{r}^{2}=0.587, \mathrm{p}=0.004\right)$.

782

783

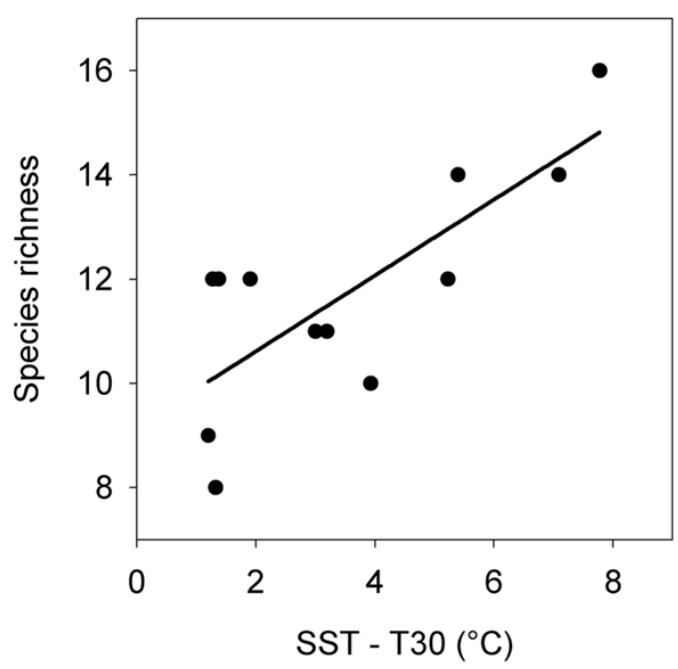

784 